\title{
AN AUTOBIOGRAPHER'S LIFE IN IOWA
}

\author{
By A. U. CoAtes ${ }^{1}$
}

I was born in a log house at Excelsior, Richland county, Wisconsin, June 21, 1858, son of William Harvey Coates and Anna Frances (Knowlton) Coates. Father was born near Montreal, Canada, and mother in Calloway county, Missouri. They were married at Castle Rock, Wisconsin, January 14, 1857.

The fall after I was three years old, I went with my uncle, who was several years older than I, to carry dinner to the men chopping in the timber. Returning, we were chased by hogs that had spent the summer in the woods and were like wild. Uncle told me to climb on a large log that lay across the road, but I ducked under the log and ran more than a mile home, at what at the tire seemed the greatest speed of my life. The dog that has caused the attack belonged to my uncle and, staying with him, saved me from being torn to pieces by the infuriated hog. I still have great fear of an angry hog.

Father and grandfather built a "grist" or flour mill that ground with "burrs." They also built a saw mill and named the place Excelsior. Some years later a railroad came through and a town came into existence about a mile west and the name remained the same.

I remember seeing a wild deer a short distance north of our house, for it stood on the high hill a long time. Father went west in 1864 to dig gold in the Rocky mountains. Returning he came to Boscobel and called across the Wisconsin river to Orion, where we had lived during his absence. There being no bridge he had to wait overnight for the river to freeze more solid, and the next day crossed on the ice. On this trip west father had selected Dallas county to which we moved early in 1865, traveling by train to Nevada, Story county, the end of the C. N. W.

\footnotetext{
${ }^{1} \mathrm{Mr}$. Coates was a prohibition leader of national repute, a candidate for governor of Iowa in 1901, on the state prohibition ticket. As a business man he was engaged in the sale of musical instruments many years in Perry, Iowa, removed to Des Moines in 1908, and died there January 21, 1943.
} 
railroad and the farthest point west any railroad was built at that time. We went with team to Des Moines, forded the river and stopped at the Avenue hotel, Second street and Court avenue. The next day with another team we drove to Wiscotta, an almost abandoned town, a half mile from where Redfield is now. The old stone store with public hall on second floor was torn down and all business moved to Redfield soon after we reached Wiscotta.

Very few articles were brought from Wisconsin, but I remember very well the cart father had made for me, with hubs, spokes and all, just like a regular wagon. This was considered a wonder by the boys of Redfield, for it was the only conveyance we boys had to play with. There were no small wagons so common now. We had sleds in winter. The first money I ever earned was for sodding a lawn for a neighbor at five cents per square yard. Blue grass was very scarce and could be found in small patches only.

Father built a house in Redfield with hewn sills, using a broadax to square them. It has been a long time since I have seen a broadax. Two trees he planted on the lot in 1866 are still growing there. He later built another house in Redfield and the sills, as well as nearly all the other lumber, were sawed from native trees. The finish lumber for one of these houses was hauled from Des Moines, and for the other from Boonesboro.

My boyhood chum was "Freme" Twitchell, and we were very friendly all the years I lived in Redfield. His mother made those big, long, twisted, fried cakes, and she must have thought we were always hungry, for she was very free with them, and I believe she always had them on hand. They were not called donuts, for the donuts came later and had a big hole in them.

\section{SCHOOL AND HOME EXPERIENCES}

At school we had a dipper in a wooden water bucket from which we all drank. I believe I was a favorite 
with most of my teachers, if not all, and got along extra well with the pupils. One time the teacher wanted to whip one of the boys and asked me to get her a switch. Now I knew the hazel was very easily broken so that was the kind I got, nor was it very large. The teacher said she had a mind to use it on me, and broke it with her hands and asked Elwood to get her a switch. He probably thought he would stand in with the teacher by getting a rather large hickory. You may know that I was almost a hero with the other boys, while Elwood was shunned for some days. On Friday afternoons we would sometimes choose up sides and see which could spell the other side down. We would speak pieces, now called readings. The last day of school we usually had an exhibition consisting of songs, speaking pieces and dialogues.

We children slept in a trundle bed that was made so low it could be rolled under the regular bed during the daytime. This was a great convenience for it saved room, as all the houses were small.

I enjoyed the trees and flowers and early learned their names. Words fail when I try to show my appreciation of the trees. I have been in forty-four of the states and do not hesitate to say that Iowa has the finest variety as well as the most beautiful trees of any state in the Union. I was also interested in the birds and if I saw a nest I could tell the kind of bird that built it. I was very fond of fishing and rarely failed in catching a good "mess" for the river was well stocked with fish.

As a boy I never saw any silver money; all paperfive, ten, twenty-five, fifty cents. I have some of this money now.

All of the boys, many of the men, and some of the women, went barefooted during the summer. I had sore toes much of the time for I was clumsy and awkward. I was also bashful and backward, and somewhat slow 
of movement and speech; was heavier at the age of sixteen than at any time in my life.

As a boy I did not like to attend school, and told my parents I would pull weeds in the garden if they would let me stay out. Thinking this would cure me of wanting to miss school they said alright. So I pulled weeds and really enjoyed the work. Next day when school time came I started for the garden, but while they gave me credit for working faithfully the day before, they said they thought I better attend school.

Father bought five acres of land across the river from Redfield, and after building the house told me I could have all I raised on as much of the land as I cleared of timber and brush. I enjoyed this kind of work and cleared much more than anyone thought I would. The first year I planted potatoes, but had to dig them early because they began to rot in the ground. This place across the river was called Omaha, and was to rival Omaha, Nebraska, when the railroad came through.

When the Christian church was to be erected in Redfield, the Masonic lodge joined in the expense and had their lodge room on the second floor. I have been in church services when the lodge was in session above. I think this arrangement lasted for about twenty years. I believe there was little conflict, for both tried to dodge the other's dates. Many of the men were members of both church and lodge.

All men and boys wore boots made mostly by local cobblers. Was I proud when I got my first pair of copper-toed boots? I was also proud when I got my first pair of pants, for boys then usually wore dresses until they were about seven years old. All clothing for women and children and most of that for men was made in the home, sewed with needle by hand. In 1867 father paid eighty-five dollars for a Wheeler and Wilson sewing machine that was a great help to women's work. About the time of which I am writing the kerosene lamp took 
the place of the tallow candle and many feared they would explode.

\section{A VISIT FROM THE GRASŚHOPPERS}

In 1867 the grasshoppers came in vast numbers, filling the air so full we could look at the sun at noon day without the aid of colored glasses. They bored holes in the ground in which they deposited their eggs that hatched the next spring. The "hoppers" ate every green thing in vegetation, until their wings grew, when they took flight in an easterly direction. They seemed to have some sort of signal, for they all left at once in a very orderly manner. Where they came from, or where they went, was never definitely known.

For a time father kept a furniture store and made about all the kinds of furniture then used. A very few got along without a cook stove by cooking in the fireplace. If a family had a cook stove, a few chairs with possibly one rocker, a table, a cupboard in which to keep a few dishes, and a bedstead, they would be prepared to go to housekeeping. Board slats were used in the bed to hold up the tick filled with straw. No springs came until many years later. Father always kept walnut lumber on hand and as long as we lived in Redfield made coffins. These were made in the old style and supposed to conform somewhat to the body, being narrower at each end than in the middle. Coffins were never made until the death occurred. The body was measured and the coffin made to correspond to the size required.

Father made a yoke with bows for the two calves we had, and I taught them to drive like oxen. There were many ox teams seen in the fields and some on the roads, although they were very slow travelers. We certainly would think so now when compared with the speed at which we are traveling.

Indians could be seen often, and they would come around begging. If they had a papoose it would be strapped to a board, and left leaning against the house. 
It would be carried on this board and a strap around the squaw's head would keep it from falling. Some were fearful of the Indians and would give them what they asked for to get rid of them.

There was great excitement in Redfield when two wellknown young men and two horses disappeared one night. So far as I know they were never heard from or the horses found. It was about the last horse stealing, that had been rather common. The penalty for horse stealing, if caught, was hanging without the aid of judge or jury.

All stockings were knit by hand. When mother was knitting her fingers went so fast I could hardly see them. She knit socks for me after she was eighty years old. Said she liked to knit and wanted something to do. Since mother is gone sister Alta has taken her place to keep me in warm socks.

\section{Early Settlements Along Streams}

The first settlements were made along the rivers and streams where there was water and timber, the two things of greatest importance to the early settlers. The "wild land" joined the towns. Many farmers cleared timber off their lands to plant crops, and had to work in fields full of roots and stumps. They evidently thought that crops would not grow on the prairie land. Farms were fenced with rail fencing and the homes and gardens with boards or pickets.

I learned to sew when I was but a small lad and sewed carpet rags to make the only kind of carpet I remember of seeing at that time. There were people who had a loom, and they would throw the shuttle back and forth by hand to weave the rags into carpets. We thought we were fixed about right when we had a rag carpet on the floor of the front room.

My first farming was carrying water to the harvest. hands for a farmer living two miles east of town on what to me was a very large farm. I later learned that it contained forty acres. I stayed with the farmer a few 
days after the grain was cut, and was supposed to be helping him with his work. He gave me a Chester White pig for my services (?).

I thought I saw a big fire when the woolen factory burned one night. There were many mills along the river where we would take the wheat and corn to be ground. We did not pay for the grinding, but the miller took a "toll" or share of the grain for his services. In a distance of twenty miles along the middle Coon river passing through Redfield, there were five flour mills and two woolen factories in operation at the same time.

Babies were kept much of the time in a cradle that was made like a box with rockers, so the women could rock the cradle with a foot while sewing or knitting. Sometimes the older children were asked to rock the cradle, which lot often fell to me, for I was the oldest child in our family.

One of the great delights of my life was when father took us for a ride in a lumber wagon, usually on a Sunday afternoon. Mother and father occupied a spring seat and we children had a board, sometimes covered with a folded quilt for our seats. We would go far in the country, and in later years when I recalled the roads we traveled, realized we must have gone five miles on our longest drives.

We had dark brown sugar only. When the light brown came, we thought it quite an advance. Granulated came much later.

The stage coach that had been the only public conveyance out of Des Moines and across the state was discontinued in 1869. There were no banks, but the money loaner of the community loaned money at two per cent a month. I heard him say that he had made it a rule to lay up a hundred dollars each year, but had to live cheaply to do it. 


\section{A "Plug" for Dallas County}

As a boy I sometimes wondered how father came to choose Dallas county for a place to live, but since traveling over much of the country I can see he made no mistake, for there are very few places that can anywhere near compare with "good old Dallas county." There was very little tame fruit, so we depended on the wild. I knew where the plums were the largest, wild crab apples the best, which meant the yellow kind. I knew where the largest and best blackberries, strawberries and other fruit was to be found. Walnut and other nut trees I had carefully located for the time they would be ripe. In fact, I knew the timber all around the town. I remember when some of the school children first brought tame gooseberries to school, for they were so much larger than the wild ones I was in the habit of getting. I still like the wild fruit best.

There was a maple sugar camp about a mile west of Redfield, as well as in many other places in this part of the state. I believe they are all gone. They would be profitable now, for the prices of maple sugar and syrup have increased several times since then. The hard maple is our most beautiful native tree, although a very slow grower, and makes the best firewood grown in this latitude.

I was very fortunate to have for my Sunday School teacher Panthia Maulsby. She was an accomplished, educated and talented lady and taught my class for nearly ten years. She taught me to sing the first songs I ever learned and I remember some of them now. She played the melodeon for Sunday school, but when church time came it was pushed back in the corner, for some of the members objected to its use in their church service.

August 8, 1869, I saw the total eclipse of the sun when it was so dark the chickens went to roost in midafternoon. 


\section{WHEN LiQuor Flowed FREELY}

The same year I saw the leading women of the town with hatchets (Carrie Nation style long before her day) destroy the liquor in the saloon that was running contrary to law, which is the common method of conducting saloons. As the beer ran along the street (there were no sidewalks in the town) I saw a man go down on his hands and knees and drink of the beer as it ran in the gutter. And I well remember that he said "it was just as good as if it just came out of a jug." I didn't believe it then, but later became fully convinced he told the truth.

The leading bootlegger had a team and he hauled freight from the railroad station (Dexter) to Redfield. One day the saloon keeper went with him for a load of liquor, and after drinking freely they got into a drunken fight. The saloon keeper had very long whiskers which the bootlegger pulled out by the roots, making a very sore chin that was a long time getting well, I remember.

Some of us boys were playing around a large boulder nearly covered with stagnant water, found when getting out that we had plenty of leeches on our bodies. We had to pull them off of each other. This experience with the fact of seeing snakes in the water, no doubt is why $i$ never learned to swim.

Stuttering in the Coates family was very common. Father stuttered all his life, and he had two brothers who stuttered worse than he did. I stuttered until I was nearly grown when I decided to quit. It took me more than five years to learn that a habit well formed is not easily broken. I can now talk as fast as most people with no sign of an impediment in my speech.

So many articles are now used for food that were never dreamed of in pioneer days. Some things were used then that are not thought of for food now. I have eaten sheep sorrel pies that were sour somewhat like pieplant. The sunbonnet was about the only kind of head- 
gear worn by the women. I remember when the women wore hoops, but they were very early discarded. A woman came to Redfield bringing a square piano, and to our surprise she could play a tune on it.

One of the most prominent people in town was Doctor Maulsby, who was raised a "Quaker" and used some of that dialect. I believe he did more laughing than anyone I ever knew. When going into the sick room he would say "Is thee sick?" And then he would laugh. After laughing for some time he would say, "That is too bad if thee is sick." And then came more laughing. It was not a simple smile, but as loud a laugh as you would hear on any occasion, and would be kept up during his entire visit. It was said by some that his laugh cured more than his medicine. There were many prominent and important people in and near Redfield, for nearly all the pioneers were very high-class citizens, whose word was as good as any bond.

When the Rock Island railroad was being built the company asked the townships they were to cross to vote a tax to help in the construction of the road. Some townships voted favoring the tax, but some of the people of Redfield claimed that inasmuch as the town was on the old stage line across the state, the road would be built through Redfield whether the tax was voted or not. Others said that the hill near DeSoto was too steep for the trains to climb. At any rate, the road missed Redfield, and the plan to extend the town south failed. Trees had been planted where the streets were to be and some of them are now growing along First Avenue, now Highway No. 6.

\section{EXPERIENCED FARM LIFE}

I have always worked in the garden and being very much interested in growing vegetation, kept urging father and mother to move on a farm. Father was not a farmer, but to please me in 1871 rented a farm five miles north of Redfield for a term of three years. I took to 
the farm and was delighted with the work, not wanting to go to town for any purpose.

By this time I was large enough to handle a gun, and with an old muzzle-loading army musket, did some hunting, for game was very plentiful. In shooting my first goose, I was down on one knee, and the load in the gun being a little larger than usual, it kicked me flat on my back, making my shoulder lame for several days. The goose was very large and I was proud of my kill. There were great flocks of prairie chickens that would eat much grain if left in the field. We would shoot the gun to scare them away. When we wanted them to eat, we would trap them and catch as many as three dozen in the trap at one time. In the spring during the mating season we would hear them "drumming" mornings and evenings. I trapped many kinds of game.

For two years on the farm we made cheese instead of butter. Farmers made their own soap that was called soft soap. There were no fancy or perfumed bars such as are in use now. A "hopper" was built and filled with wood ashes; then water was put on the ashes, which when soaked through came out lye. This was the kind of lye used in making soap. It was also used to hull the corn to make hominy.

I attended school winters and a Mrs. Davis was in some of the same classes. She was past sixty years, and living with her second husband. Her first husband had had a good education while hers had been neglected, and she was trying to be the better prepared to meet her first husband in the next life. She learned slowly.

While nearly all grain was cut with a reaper, I have cut wheat with a cradle and threshed it with a flail. Farm machinery was not very plentiful. I have used wild crab apple bushes to smooth the ground instead of a harrow.

We sometimes had trouble breaking colts. I was on one once when it became frightened, throwing me off, 
and father carried me into the house unconscious. I came to myself soon and could not understand why I was in a strange bed, for I had no pain and got up as soon as they would allow me.

In 1874 father bought an eighty-acre farm ten miles north of Redfield, paying twenty dollars per acre. Improvements were rather good for that time, but upstairs where I slept was not plastered, and some mornings I would find my bed white with snow that drifted in during the night. Some cold came in also. We had for the stock what was called an "Iowa stable"-poles with slough grass hay over them for the roof, and frames made of poles and filled with hay or straw for the sides. Yes, they were warm.

\section{Forest Fires Made Prairie Land}

There were many ponds on the prairie, all on the higher ground, and some of them contained fish. I could stand in the door of our house and shoot ducks and sometimes geese on the pond near. All these ponds are drained now. There was much open country and a prairie fire was to be dreaded. I never timed them, but have been told that they sometimes travel as fast as a horse runs. The most spectacular fire I ever saw was a prairie fire when it looked like the entire country was burning. Had it not been for these fires this entire state would have been timbered. The fires kept the trees from growing on the level land.

In summer we wore genuine straw hats for they were made of braided oat straw. The women would sew the braid together making the hat, which was not always in perfect shape, although many were well fashioned and looked fine.

I herded cattle the summer of 1874 , with three hundred twenty-five head in the herd. One hundred and ten of them were Texans and wild when I was off my horse, but when herded on horseback were just as tame as the natives. We kept them at night in a rather long corral 
near the house. They were frightened and stampeded one night, running from one end of the corral to the other for more than two hours. Father was at one end of the corral and I at the other trying to get them quiet. Had they broken through the fence as we feared they might do, they would have trampled us to death, in all probability, a fact we did not consider until the excitement was over.

A pair of cranes was hatched and grew up on the prairie where I herded, as well as a few ducks and geese. All went south in the fall. Many prairie chickens were hatched on this prairie, and when they began to fly, I would get some of them with my whip, for they were just right for frying.

The lily was my favorite of the many flowers growing on the prairie. The wild sweet williams were especially abundant, the prevailing color being red, but many were striped and some almost white. One could not help admiring the wild rose.

\section{BeCAME A SCHOOL TEACHER}

I had plenty of time during the long days, and after reading all the books handy, took my school books and studied them. This proved a very wise thing to do, for the next spring I looked for a school to teach, and found one just over in Guthrie county, which I might have if I could get a certificate. I went to Guthrie Center and after finishing the examination, expected to go home, when the superintendent said if I would stay overnight he could tell if I got a certificate or not. Now this was for a longer time than I had expected to stay away from home, and I was out of money.

The hotel man had a large pile of wood, and I told him I would saw wood to pay him if he would keep me overnight, and he said alright. The superintendent lived at the hotel and he saw me sawing wood. I have always believed that the sawing of wood had much to do with my getting a certificate at that time. I had given my 
age correctly, although I know I would not be allowed to teach until I was eighteen years old. The superintendent asked me when I would be eighteen and when I told him he scratched out seventeen and wrote eighteen on my examination papers. He also said my grades were too low to get a certificate, but were very even, being only ten per cent from the highest to the lowest in the different branches, and he would raise the grades and give me a certificate.

That afternoon I walked twenty-three miles to where I was to teach, staying over night with the sub-director, and walked the eight miles home the next day. My pay was twenty-five dollars per month, and I paid two dollars per week for board and room. I taught the next four winters at a salary of thirty-five and forty dollars. I received a first-class certificate after the first term.

The Fourth of July, 1876, I went to the neighborhood where we had lived and in a lumber wagon went to Dexter for the celebration. Returning after night we were drenched with as hard a rain as I think I ever saw. - When we reached the place from which we started, and learned that a small bridge farther on was washed out, prepared to stay overnight. We men started for the barn to sleep in the haymow, when we learned that the barn had been struck by lightning, and my horse, the first one I ever: owned, was killed. This caused us to return to the house, where we slept on the floor and covered the large room. The next day my friend took me within a mile of home when we came to a slough we dared not try to cross even on horseback. There had been much rain that summer. I took off part of my clothing, waded the slough, and walked the mile home, carrying my saddle and bridle, feeling very gloomy over my loss.

\section{MUdDY ROADS ALL WINTER}

The winter of 1876 and 1877 was very warm. I saw some of my neighbors plowing in the fields every month during the winter, and they might have plowed much of the time but for the mud. Roads have never been so bad 
as they were practically all that winter. Ice did not form four inches thick any time during the winter. Some ice was shipped in from the north the next summer. Not so much ice was used then as later. I was teaching school and part of the time went horseback. There was one place in the road so bad that I would get off my horse for fear he would get stuck with my added weight.

The spring of 1878 came very early and crop conditions promised good. I planted corn April 26th and some farmers even earlier than that. Vegetation was far advanced when on May 10th and 11th there came a big snow and froze nearly all the new growth. Some corn was three inches high and was killed to the ground, but came out all right. A snowball bush in full bloom froze so that all the new growth was killed. Grapevines with a growth of more than four inches were killed, but came out again and made a small crop.

We lived forty-five miles from Des Moines and drove there falls with wagon boxes full of turkeys and sold them for a dollar each. I planted many trees, bushes and fruit on the farm. It was eight miles to the nearest timber and ten miles to the nearest town. We depended largely on what we raised for our living, and when some crop failed we usually did without. The wheat crop was poor one year and we used much corn meal that was not to my liking. We made sorghum molasses that was used for syrup and it helped to take the place of sugar for some purposes. We put up some fruit, but no vegetables or meat was being canned at that time. The prevailing price of chickens was twenty-five cents, potatoes twentyfive cents per bushel. Corn varied more, but usually near the twenty-five cent price. These prices prevailed for many years.

Singing schools, spelling schools and debating societies furnished the common means of entertainment and I spent many winter evenings at these places. We traveled mostly horseback, which was the common mode of travel for men. Women rode horseback much more than they 
do now, using a side saddle, but never astride as they do now. There were a few spring wagons and the top buggy was just coming into use. However, the lumber wagon was the common method of travel, and you would sometimes see a young man taking his "best girl" for a ride in a lumber wagon. Father sold the farm in 1879 and we moved to Minburn, engaging in the farm machinery and hardware business. I regretted very much leaving the farm and for several years expected to go back to farming.

\section{First Public Speaking for Prohibition}

The temperance question was to be voted on June 27, 1882 , as an amendment to the state constitution prohibiting the sale of liquor in Iowa. I was very much interested in the campaign and did my first public speaking for this amendment, which carried by a majority of 30,000. However, the Iowa Supreme court said it was not passed in a legal manner. The words "to be" were omitted in one place by the senate clerk in engrossing the bill. Many believed, as I still do, that the error was made on purpose for an excuse to defeat the will of the people and retain the saloons.

In 1883 I went west by the way of Denver to San Francisco, where I got my first view of the ocean. Then three days on the Pacific ocean to Portland, eating nothing while on the boat. I certainly was seasick. Then I went from Portland thirty miles south to a small town where two former Minburn, Iowa, families lived. I was well pleased with the Williamette Valley. Seven of us crossed the coast mountains to Tillamook bay on the ocean.

We hunted and fished with poor success; but saw many strange sights such as a star and jelly fish. We helped ourselves to oysters and clams and lobsters. I wanted mine cooked. July 4 th we went with a few families up in the mountains deer hunting, where we camped four days. The next day I was stationed on the banks of a mountain stream at four o'clock in the morning with a 
gun across my knees waiting for the deer that never came. Just at noon the hunter above me came down the bed of the stream, for the brush was too dense to walk through with a yearling he had killed. I did not see a live deer, but some of the party got from one to three each day. The method of hunting was to turn the dogs loose on the mountain side and when the deer were chased they would run to water, so the dogs would lose their trail. We were stationed where we thought the deer would cross the creek. There I had my first venison and bear meat. I liked both, but did not take to the vension "jerk," which was a piece of meat fastened on a stick and held in the smoke and flame to cook.

I visited Seattle and other places, spending much of the summer on the Pacific coast, and returned over the N. P. R. R. which was not finished at that time. We staged from Missoula to Deer Lodge ninety miles, and the next day to Helena forty-five miles; then took train through St. Paul and home. Ever since I can remember I had wanted to go to Oregon, although I never knev. why. This was a most wonderful trip for me at that time. In 1884 three of us drove west into Nebraska and Kansas, then back through Missouri. I stopped off at Des Moines and as a delegate, attended the Grand Lodze of the I. O. G. T.

\section{First State Fair at Des MoInes}

The first time the State Fair was held in Des Moines it was on the west side of the river in 1879. I was attending the teachers' normal at Adel. Taking my "best girl" we left Adel on a narrow gauge railroad in a flatcar, with two-inch plank fastened crossways of the car for seats. I still have the beaded watch pocket this girl gave me that she bought of some Indian women who were selling beadwork at the fair. I attended every fair held after that time until 1927. Early in 1885 I visited the world's fair at New Orleans. Many articles were given away, not like the recent world fairs, where everything on display seemed to be for sale, and that was the 
only reason for being there. California at a certain hour gave everyone an orange. A thread company gave every lady a spool of thread she had seen made. Many trinkets and novelties were given away. There was a "dummy" line to show how street cars could be run by electricityI think the first ever built. Very soon after that time all street cars were run by that power. I went down the river to get to the gulf of Mexico, and had to look down from the boat to see the fields and orange groves. Great levies held the water, which if broken would do untold damage.

The same year I married Miss Margaret E. Riley of Iowa City, and engaged in the music and sewing machine business at Perry. Commenced in a small way, driving through the country for several years regardless of conditions of roads or weather. In 1888 made a trip east through Chicago, Washington and New York. On boat to Boston and Portland, then on train to Montreal, Niagara Falls, Detroit, Chicago and home. I visited the world's fair in Chicago in 1893 and was on the grounds "Chicago Day" when there were 723,000 paid admissions. I have visited six world fairs.

In 1885 eighteen of us who had voted for John P. St. John for president the year before, met in the Polk county court house in Des Moines and organized the Prohibition party in Iowa, and I have attended every convention the party has held since. I was chairman of four conventions and secretary several times, and now am chairman of the state and a member of the national committee. In 1901 I was candidate for governor of Iowa and polled the largest vote the Prohibition party has ever cast in this state. My home town of Perry treated me very well indeed, for my vote was larger than that of the Democratic candidate in two of the three wards of the town. The state convention recommended the action and selected the delegate who presented my name for nomination as vice president at the national convention at In- 
dianapolis, Indiana, in 1904. But a peculiar condition developed, as often does at such places, causing me to withdraw as a candidate.

\section{SOME TALENT AS MUSician}

I have spent much time in the study of vocal music and can read quite readily any ordinary songs. My knowledge of music enabled me to get out a chart to play chords for singing, the simplest I think I ever published. In selling instruments I could not play the music, so I learned more than 200 songs of various kinds, and would play the chords and sing the songs to show off the piano or organ. I have taught vocal music, led singing in choirs, revival meetings and other public gatherings. My last choir singing was in the University Place Christian church in Des Moines. I have written a few songs, two of which were published in glee club songbooks. In $1904 \mathrm{I}$ organized the music dealers of the state, being the first state ever so organized, and became president.

About 1874 some smooth wire was used by the prairie farmers for fencing, but was not a success until a tool was made to fasten barbs on the wire, which worked better. Then came the double twisted wire with barbs fastened securely, and this kind is still in use. In 1894 I rigged up my spring wagon with cover, so I could sleep in it and drove to West Branch. The next year I drove to the northwest county of Kansas and traded the team and wagon for a hundred sixty acres of land near Goodland. In $1900 \mathrm{I}$ bought a brick block in Perry of three store rooms and living rooms on the second floor. I was in the music business when so many organs were being sold. I bought a hundred twenty organs at one time and sold nearly three hundred that year (1901). This, besides the sewing machines, pianos and other music goods, for I had a full line of small goods and sheet music.

In 1902 I traded this block for a thousand-acre stock ranch in southeast Kansas near Mt. Ida. It was known 
as the "Mule Ranch". In 1907 I moved to this ranch and worked all the daylight the year I was there, enjoying the farming as I always had. This ranch was my dream of many years: one hundred forty acres of bottom land, thirty acres of timber, running water on every quarter section and wonderful grazing land. But the latter part of the summer when I found a snake on top of the cupboard in the kitchen, I said not another summer here. Snakes and I do not live in the same house at the same time. I had a stick like a cane at every door and gate on the ranch, to be used for killing snakes. The two barn lots were fenced with stone, and there were three miles of stone fence on the place. This kind of fence made excellent harbor for snakes as well as other creatures. There were only a few rattlers and copperheads.

I got a hundred thirty-eight head of cattle with the ranch, of which half were purebred registered Galloways, and as fine as I ever saw at any fair. I learned that robins do not go far south to winter for some stayed on my ranch all winter. Moved to Des Moines in 1908 and the next year traded the ranch for twelve houses and some lots in Des Moines. This put me in the real estate business, which I enjoyed, and in which I made money easily. The trading I especially enjoyed.

I was secretary of the Prohibitory Amendment association, which meant manager and lobbying in two sessions of the legislature. I have been active in the state in every contest for temperance and prohibition since my first one in 1882.

I was chairman of the convention that nominated Dr. B. O. Aylsworth, president of Drake University, for governor. He was a delegate to the convention and accepted the nomination saying he would make an active campaign. Gen. J. B. Weaver was a visitor at the convention, and told me that with Aylsworth's nomination and the platform we had adopted he would recommend that the Greenback party make no nomination for the office of 
governor. This would have added many votes with a possible union of the two parties. But this was not to be for the trustees of Drake University told Mr. Aylsworth to either decline the political nomination or retire from the university. He withdrew as a candidate.

In 1916 when J. Frank Hanley, former governor of Ohio, was our candidate for president, the party had a special train and he and the national chairman (O. W. Stewart) spoke in some of the towns through which we passed. On invitation I rode on this train from Alton in the northwest part of the state to Council Bluffs where we spent the night, and then to Ames where I left the train.

* $\quad * \quad * \quad * \quad * \quad * \quad * \quad *$

In 1910 I got together some of the people living in Polk county who formerly lived in Dallas county and we had a banquet in the winter and a picnic in the summer. My wife died in 1922 but I kept my home the same as it had been and went to Los Angeles where mother was spending the winter with relatives. Returning in the spring I left mother with my sister at Fort Collins, Colorado, where she had been staying since father's death in 1917. I had helped father and mother some during their last days. . . . I sent for mother and my two sisters, of course paying the expense, to visit me in my home at 3408 Cottage Grove Avenue before I broke up housekeeping. . . . Mother died soon after returning to Colorado, and I accompanied her body to lay beside father's at Florence, Kansas.

\section{RETURNED TO SCENES OF BOYHOOD}

In $1923 \mathrm{I}$ went to Redfield and fished just below the dam where I had fished more than fifty years before. Had rather good success for I caught ten channel catfish. The river looked so much smaller than it did when I was so much smaller. The same year I was driving between Pomeroy and Pocahontas when the steering gear became detached, giving me no control of the car. It ran into 
the ditch at the side of the road, landing bottom side up, breaking the windshield and bows (it was a touring car), then on over rightside up with the front of the car in the field and the back wheels against a bank of dirt. The rim of one wheel was off and sixty feet from the car, and my pocket knife came from the bottom of my pants forty feet from the car. I was under the steering wheel all the time and knew just what was happening. The rim and two braces of the steering wheel were broken. From the first I expected to die but was not concerned about it, thinking I might as well die then as any time. I even picked out a place to lie down and die when I should get weaker. My face was bleeding freely and I expected to find a hole in my head for I was hit all over. Not finding the hole in my head I learned that the blood came from my nose only. The doctor found two broken ribs, but when I told him my neck was broken he said "no". But it was some wreck.

I attended the Coates family reunion in 1903 at Osborne, Kansas. When changing cars at Concordia to the M. P. R. R. a cousin came to me and asked if my name wasn't Coates. This cousin I had not seen since she was six years old and I was twelve. She judged by the family resemblance which I showed very plainly. Father was the oldest of six brothers and a sister whose average age at that time was sixty-three years. I was and still am the oldest cousin.

Late in 1923 I married Mrs. Isabel (Lein) Metcalf of Des Moines. The next year we made a trip west, visiting Estes Park and other places in the Rocky Mountains. Visited my sister at Fort Collins and Belle's relatives in western Nebraska. Then through the Pine Ridge Indian agency to the Black Hills. Next to Yellowstone park which we found very interesting with Old Faithful, the geyser, that throws hot water and steam nearly two hundred feet high every sixty-five minutes. . . . Everything is kept as nearly as possible in its natural condition. You may know it is cold there when July and August 
are the only months the park is open to the public. We were there the 26th of August when the thermometer went down to twenty degrees. Ice formed thicker than a window glass, a heavy frost on everything, but not a bush, leaf or flower was hurt. Were it not for these geysers I have no doubt this mountainous country would blow up. There are so many geysers, though nearly all small.

* $\quad * \quad * \quad * \quad * \quad * \quad *$

The "depression" came about 1929, when I traded one of my properties for a stock of groceries and have been in the grocery business since, having moved to one of my wife's houses in East Des Moines and built a store room adjoining. But, before opening of this new location in 1934, we went to the world's fair in Chicago. . . . The only sickness I ever had was in 1932, when I was laid up for a week with the flu; and have had no other sickness for a single day, but able to be up and around, doing whatever was necessary. I am reaping the benefits of a clean life.

No one could have better parents than I had, and with satisfaction I recall that I never spoke a cross word to either of them after I was grown. Father did not like farming, but lived on a farm eight years just to please me .. The past has held much for me in way of varied experiences and interesting friendships, and now having passed my eightieth birthday I enjoy an occasional reflection on the days gone by.

\section{TRAINING IOWA FIREMEN}

Twenty-six years ago Iowa State College at Ames commenced training fire fighters. The class has increased in numbers steadily and this year 484 have taken the course in fire prevention and protection. This training has been taken up since in colleges and universities to aid in the work of cutting down the annual fire loss of the country which is enormous and much of it preventable. Iowa has led in this important work. 
Copyright of Annals of Iowa is the property of State of Iowa, by \& through the State Historical Society of Iowa and its content may not be copied or emailed to multiple sites or posted to a listserv without the copyright holder's express written permission. However, users may print, download, or email articles for individual use. 